\title{
Erratum to: Bioaccumulation in aquatic systems: methodological approaches, monitoring and assessment
}

\author{
Sabine Schäfer ${ }^{1 *}$, Georgia Buchmeier ${ }^{2}$, Evelyn Claus ${ }^{1}$, Lars Duester $^{1}$, Peter Heininger ${ }^{1}$, Andrea Körner ${ }^{3}$, \\ Philipp Mayer ${ }^{4}$, Albrecht Paschke ${ }^{5}$, Caren Rauert ${ }^{3}$, Georg Reifferscheid ${ }^{1}$, Heinz Rüdel ${ }^{6}$, Christian Schlechtriem \\ Dieter Schudoma ${ }^{3}$, Christa Schröter-Kermani ${ }^{3}$, Foppe Smedes ${ }^{8,9}$, Dieter Steffen ${ }^{10}$ and Friederike Vietoris ${ }^{11}$
}

\section{Erratum}

The bioconcentration factor (BCF) is defined as the ratio between the chemical's concentration in organism $\left(\mathrm{c}_{\text {organism }}\right)$ to the respective concentration in water $\left(\mathrm{c}_{\mathrm{aq}}\right)$. The following corrected formula substitutes for formula (1) as printed on page 2 of the article by Schäfer et al. [1].

$$
\mathrm{BCF}=\frac{{ }^{C} \text { organism }}{{ }^{C} a q}
$$

Received: 31 March 2015 Accepted: 26 May 2015

Published online: 30 June 2015

\section{Reference}

1. Schäfer S, Buchmeier G, Claus E, Duester L, Heininger P, Körner A, Mayer P, Paschke A, Rauert C, Reifferscheid G, Rüdel H, Schlechtriem C, SchröterKermani C, Schudoma D, Smedes F, Steffen D, Vietoris F. Bioaccumulation in aquatic systems: methodological approaches, monitoring and assessment 2015. Environ Sci Eur. 2015:27(5):1-10.

\begin{abstract}
Author details
'Department of Qualitative Hydrology, Federal Institute of Hydrology, Am Mainzer Tor 1, 56068 Koblenz, Germany. ${ }^{2}$ Department of Aquatic Toxicology, Pathology, Bavarian Environment Agency, Demollstr. 31, 82407 Wielenbach, Germany. ${ }^{3}$ German Federal Environment Agency, Am Wörlitzer Platz 1, 06844 Dessau, Germany. ${ }^{4}$ Department of Environmental Engineering, Technical University of Denmark, DK-2800, Kongens Lyngby, Denmark. ${ }^{5}$ Department of Ecological Chemistry, UFZ-Helmholtz Centre for Environmental Research, Permoserstraße 15, 04318 Leipzig, Germany. ${ }^{6}$ Department of the Environmental Specimen Bank and Elemental Analysis, Fraunhofer Institute for Molecular Biology and Applied Ecology (IME), Auf dem Aberg 1, 57392 Schmallenberg, Germany. ${ }^{7}$ Department of Ecotoxicology, Fraunhofer Institute for Molecular Biology and Applied Ecology (IME), Auf dem Aberg 1, 57392 Schmallenberg, Germany. ${ }^{8}$ Deltares, PO Box 85467, 3508 AL Utrecht, The Netherlands. ${ }^{9}$ Masaryk University, Recetox, Kamenice 753/5-A29, 62 500, Brno, Czech Republic. ${ }^{10}$ Lower Saxony Water Management, Coastal Defence and Nature Conservation Agency, An der Scharlake 39, 31135 Hildesheim, Germany. ${ }^{11}$ Department of Questions of Principle of Water Management, Water Quality of Surface and Ground Water, Water Supply; Ministry for Climate Protection, Environment, Agriculture, Nature Conservation and Consumer Protection of the German State of North Rhine-Westphalia, Schwannstraße 3, 40476 Düsseldorf, Germany.
\end{abstract}

* Correspondence: sabine.schaefer@bafg.de

${ }^{1}$ Department of Qualitative Hydrology, Federal Institute of Hydrology, Am Mainzer Tor 1, 56068 Koblenz, Germany
Submit your manuscript to a SpringerOpen ${ }^{\circ}$ journal and benefit from:

- Convenient online submission

- Rigorous peer review

- Immediate publication on acceptance

- Open access: articles freely available online

- High visibility within the field

- Retaining the copyright to your article

Submit your next manuscript at $>$ springeropen.com 